\title{
空気湿電池用炭素陽極に用いる炭素の付活についで \\ Activation of Carbon of Positive Carbon Electrode of Air-Depolarized Wet Cell
}

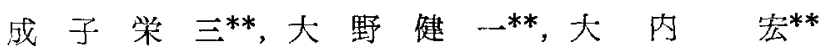 \\ Eizo Naruko, Kenichi OHNo, Hirosi OHUCHI \\ 舘 野 博 明**, 上池修** \\ Hiroaki Tatelvo, Osamu Kamine
}

\section{1. 緒 論}

空気湿電池飞組立てる前に，炭素陽極としての性能を 判定する手段の一つ原，材料宸素の過酸化水素分解能が 参考にされて来た ${ }^{(1)}$. 過酸化水素分解能は防水処理前に 測定方るから，防水処理後の炭素陽極の性能已必ずしる 平行しないが，少なくとも良好な陽極材料は通常大きい 過酸化水素分解能を示寸。著者らはこの分解能の大きい

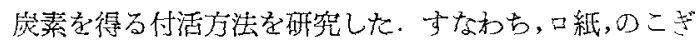

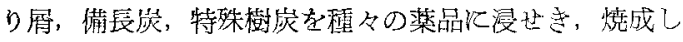

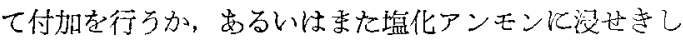

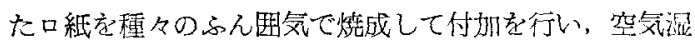
電池用炭素晹極の質の向上槣与しょうとした。

炭素と過酸化水素分解能との関係については，多くの 報告があるが，特《Walton (2) ととの共同矿究者が释細 飞研究している，著者らは前報 ${ }^{(3)}$ 飞执いて，市販空氛 湿電池用炭素陽極を縦横飞細分し，過酸化水素分解能好

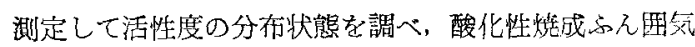
にさらされる炭素陽椣の表面が特に活性度が大きいこと を示した。

\section{2. 浸せき菂品と活性度との関係}

\section{1. 試 料}

A) 口紙炭 1 口紙（東洋口紙No.2）を常温で备

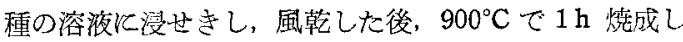

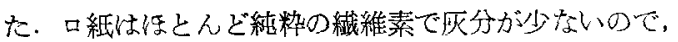

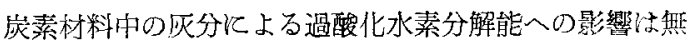
視出来る.

B） 口紙炭 2 口紙をらかしめ $900^{\circ} \mathrm{C}$ 焼成し

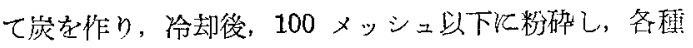

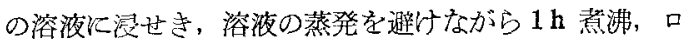

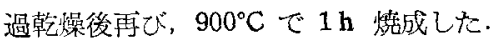

C) のこぎり肩炭 乾燥したのこぎり屏を各程溶液 に浸过きし， $1 \mathrm{~h}$ 者沸，口過乾燥後，900 $\mathrm{C}$ で $1 \mathrm{~h}$ 焼

${ }^{*}$ 昭和 31 年 4 月 29 日, 電気化学始会第 23 回大会横浜国立大学工 学部に批いて，昭和 30 年 10 月 31 日，電気化学塔会秋零大講演 会, 東京都立大学深沢校含的おいて, 講演発表济质

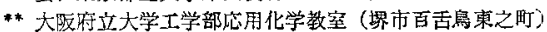

成した。

D) 備長炭 ウバメガシを高温度で炭化焼成して得 た市販の木炭を 100 メッシュ以下に粉硚し，B）と同様 の処理をした。

E) 特殊樹炭 愛媛県温泉郡坂元村, 旧四国炭鉱て 産出する木目の非常仙到っきりし天然木炭型の石炭で 水分 $4.4 \%$ ，揮発分 $35.2 \%$ ，灰分 $1.8 \%$ である. 次の 3 敇の处理を行った。

a) $3 \% \mathrm{NH}_{4} \mathrm{Cl}$ 溶液に浸せきした口紙宸 2 と同樣

b) 特列の処理家行わず。

c) $1 \% \mathrm{NH}_{4} \mathrm{Cl}$ 溶液任浸せきした口紙岑 1 と同様

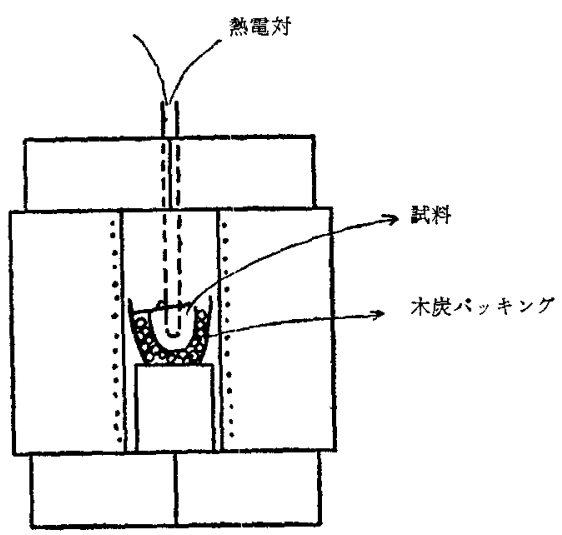

第1図付活装置

\section{2. 実験方法}

前这の試料の焼成は二珰ルッボ中で行った，外側のル ッボ中に 4〜10メッシュの木炭粉を入れ, 内側のルッボ 中試料在入れて，第1图のように，ふたをして烧成し

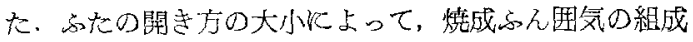
が変り，炭素の活性度も㤎わるので，禹たの開き方は慎 重に一定になるようにした。すなわら，ふたをずらして 最大 $2 \mathrm{~mm}$ 開くよう汅した。同じ状態で付活した活性炭 についての再現性は各時間の過酸化水素分解率の誤差が $5 \%$ 以内であっ论。

工業的煬極の付活は崖素粉, 結合剂, 付加剂老混合 乙，成型後，焼成するが，その時飞付活が行われる。 
の後, 付活剤を除くための特別の操作例えば氷洗などは 行われていない，活性度に上る過酸化水素分解能は $\mathrm{pH}$ に上り著しく影響される。すなわち，過酸化水素は酸性 では安定で，アルカリ性では急速て分解される。しかし 著者らは付活剂を除かず焼いたな」状態で過酸化水素 分解能を測定する方法が，工業的立場から実際に即した と考觉たので，焼いたま小の状熊で，過酸化水素分解能 を測定した，参考末で分解能の大きい $\mathrm{NH}_{4}$ 塩付活炭 素の $\mathrm{pH}$ をIS の方法に準じて測定したが，大部分 $\mathrm{pH}$ $=6 \sim 7$ で, 特別の場合飞枯いても一部分 4.4 以上の酸 性であった、いずれにしても， $\mathrm{pH}$ による影響は著者ら の場合少いものと考学る。

\section{3. 実験結果}

A. 口紙炭 2 の付活 付活口紙炭 2 の過酸化水素分 解能怔第 2 図に一括して示した.

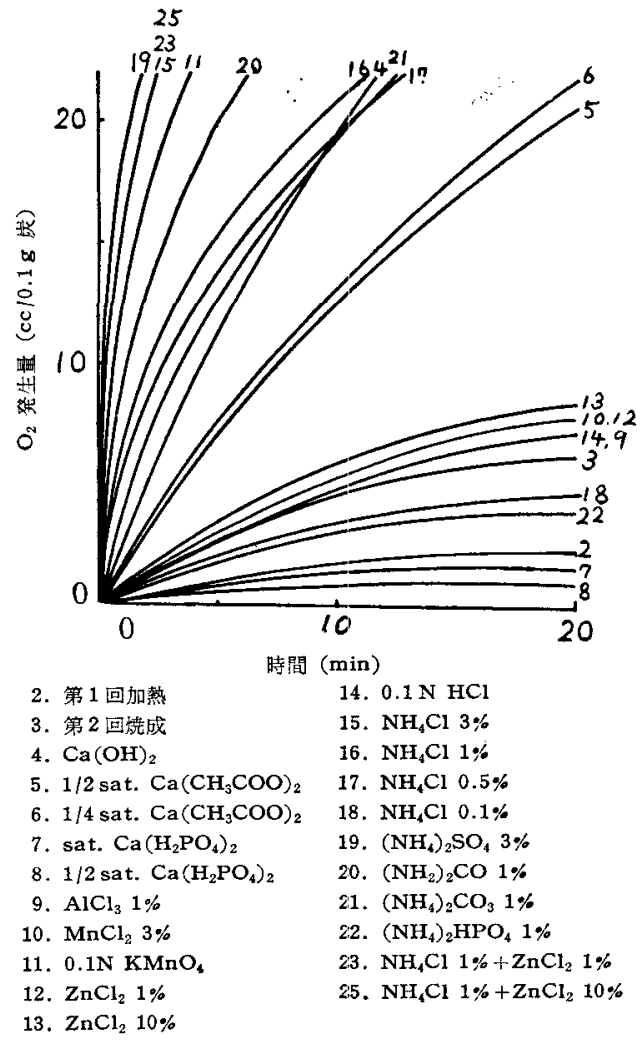

第 2 図付活口紙炭 (2) 0過酸化水素分解能

これより次のように考察される。

a) まず薬品浸せきを行わないで実験した場合，口紙 を一回㳳成しただけでは，活性度がきかわて低い，一度 冷却後, 空気中化さらし再び焼成するとわずかである が，活性度が増大する。これ性最初わずか炕付活された ために吸着した酸素招よび焼成ふん囲気により酸化され たためである。 b) $\mathrm{NH}_{4}$ 基を含导化合物一 $\mathrm{NH}_{4} \mathrm{Cl},\left(\mathrm{NH}_{4}\right)_{2} \mathrm{SO}_{4},\left(\mathrm{NH}_{4}\right)_{2}$ $\mathrm{CO}_{3}, \mathrm{NH}_{4} \mathrm{Cl}+\mathrm{ZnCl}_{2}$ 拓よび $\mathrm{NH}_{2}$ 基を含叴化合物一 $\left(\mathrm{NH}_{2}\right)_{2} \mathrm{CO}$ は, 他の化合物飞比較して著しく大きい付 活作用がある。この事実は Walton らの報告に招いて， 乳糖炭を $600^{\circ} \sim 875^{\circ} \mathrm{C}$ アンモニア気流中で処理した炭素 が活性であったこと，アミノ基を含む化合物一へキサメ キレンテトラミン，ゼラチンを炭化して活性な炭素を得 たことと関連している.

c) $\mathrm{Ca}$ を含吉化合物一 $\mathrm{Ca}(\mathrm{OH})_{2}, \mathrm{Ca}-\left(\mathrm{CH}_{3} \mathrm{COO}\right)_{2}$ で 付涺した場合，分解速度定数はそれぞれ $\mathrm{Ca}(\mathrm{OH})_{2} 2.1$ $\mathrm{m} l \cdot \mathrm{min}^{-1} 1 / 2$ sat $\mathrm{Ca}\left(-\mathrm{CH}_{3} \mathrm{COO}\right)_{2} 1.0 \mathrm{~m} l \mathrm{~min}^{-1}, 1 / 4$ sat $\mathrm{Ca}\left(\mathrm{CH}_{3} \mathrm{COO}\right)_{2} 1.1 \mathrm{~m} l \mathrm{~min}^{-1}$ となる $\left(1 / 2\right.$ sat. $\mathrm{Ca}\left(\mathrm{CH}^{3}\right.$ $\mathrm{COO})_{2}$ 怯 satC. $\mathrm{a}\left(\mathrm{CH}_{3} \mathrm{COO}\right)_{2}$ の飽和溶液を 2 倍に希积 したことを示す).

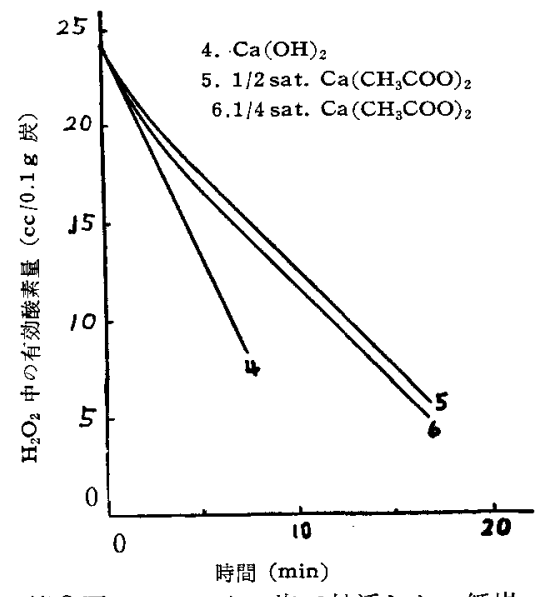

第 3 図カルシウム塭で付活したロ紙炭

(2) の $\mathrm{H}_{2} \mathrm{O}_{2}$ 分解能

これは炭素の活性化よりもむしる， $\mathrm{Ca}(\mathrm{OH})_{2}, \mathrm{Ca}\left(\mathrm{CH}_{3}\right.$

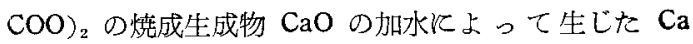
$(\mathrm{OH})_{2}$ の分解速度への影響と思われる。

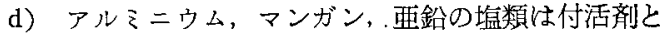
して大きな影響はない。

e） $\mathrm{PO}_{4}$ 基省含吉化合物 $\mathrm{Ca}\left(\mathrm{H}_{2} \mathrm{PO}_{4}\right)_{2} ，\left(\mathrm{NH}_{4}\right)_{2} \mathrm{HPO}_{4}$ 飞揓いては， $\mathrm{PO}_{4}$ 基はカルシウム又は $\mathrm{NH}_{4}$ 基自身の付 活効果を城じている.

f) cation $か^{3} \mathrm{NH}_{4}^{+}$の場合には, 陰イオンとして, $\mathrm{Cl}^{-}, \mathrm{SO}_{4}{ }^{2-}, \mathrm{CO}_{3}{ }^{2-}$ 汸活性度に大きな影響を持たない。

g) $\mathrm{NH}_{4} \mathrm{Cl}$ 付活と加熱温度との関係 口紙炭 2 をそ れぞれ $\mathrm{NH}_{4} \mathrm{Cl}$ の $3 \%$ 又は $1 \%$ 溶液济せき後，100， $300,500,700,900^{\circ} \mathrm{C}$ でそれぞれ $1 \mathrm{~h}$ 加熱した.このよう そして得た炭素の活性度を比較すると(第 8 図参照).

$900>300>700>500>100^{\circ} \mathrm{C}$

の順序となる. $300^{\circ} \mathrm{C}$ で付活した炭素の方が $700,500^{\circ} \mathrm{C}$ で付活した炭素よりる活性度が大きいのは興味がある。 また $500^{\circ} \mathrm{C}$ で付活した炭素は, $300^{\circ} \mathrm{C} て ゙ ~ 1 \mathrm{~h}$ 加熱後, 引きつづき $500^{\circ} \mathrm{C} て ゙ ~ 1 \mathrm{~h}$ 加熱した炭素と同じ活性度を 
示した. $500^{\circ} \mathrm{C}$ または $700^{\circ} \mathrm{C}$ に招いては一度 $300^{\circ} \mathrm{C} て ゙$

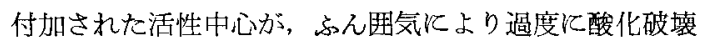
されるが, $900^{\circ} \mathrm{C}$ に执いてね通常のガス付活法の原理に よって再び付活され最高活性度を示すと考克られる。な 招このことに関して，詳細に研究中である.

B）炭素材料による付活の難易前項に括いて口紙 炭 2 亿つて，付活剂の効果を吟味したが，倩長炭，の

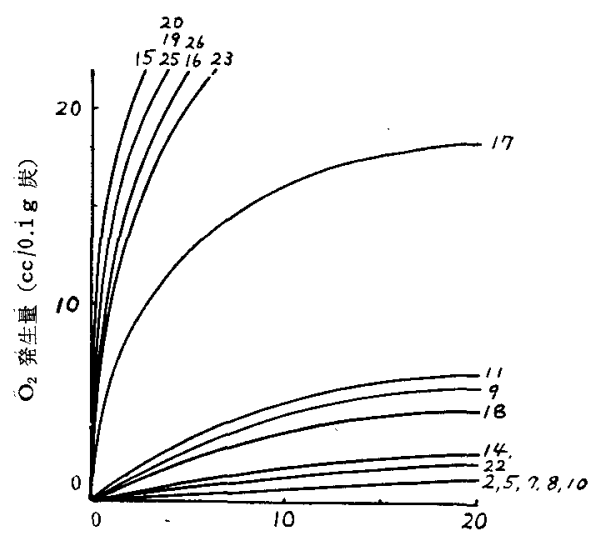

時間 (min)
2. 第 1 回熱処理
16. $\mathrm{NH}_{4} \mathrm{Cl} 1 \%$
5. $1 / 2$ sat. $\mathrm{Ca}\left(\mathrm{CH}_{3} \mathrm{COO}\right)_{2}$
17. $\mathrm{NH}_{4} \mathrm{Cl} 0.5 \%$
7. sat. $\mathrm{Ca}\left(\mathrm{H}_{2} \mathrm{PO}_{4}\right)_{2}$
18. $\mathrm{NH}_{4} \mathrm{Cl} 0.1 \%$
8. $1 / 2$ sat. $\mathrm{Ca}\left(\mathrm{H}_{2} \mathrm{PO}_{4}\right)_{2}$
19. $\left(\mathrm{NH}_{4}\right)_{2} \mathrm{SO}_{4} 3 \%$
9. $\mathrm{AICI}_{3} \mathrm{x} \%$
20. $\left(\mathrm{NH}_{2}\right)_{2} \mathrm{CO} 1 \%$
10. $\mathrm{MnCl}_{2} 3 \%$
11. $0.1 \mathrm{~N} \mathrm{KMnO}$
22. $\left(\mathrm{NH}_{4}\right)_{2} \mathrm{HPO}_{4} 1 \%$
14. $0.1 \mathrm{~N} \mathrm{HCl}$
23. $\mathrm{NH}_{4} \mathrm{Cl} 1 \%+\mathrm{ZnCl}_{2} 1 \%$
15. $\mathrm{NH}_{4} \mathrm{Cl} 3 \%$
25. $\mathrm{NH}_{4} \mathrm{Cl} 1 \%+\mathrm{ZnCl}_{2} 10 \%$
26. $\mathrm{NH}_{4} \mathrm{Cl} 1 \%+\mathrm{ZnCl}_{2} 50 \%$

第4図種々の活性剩で付活した口紙炭

(2) $の \mathrm{H}_{2} \mathrm{O}_{2}$ 分解能

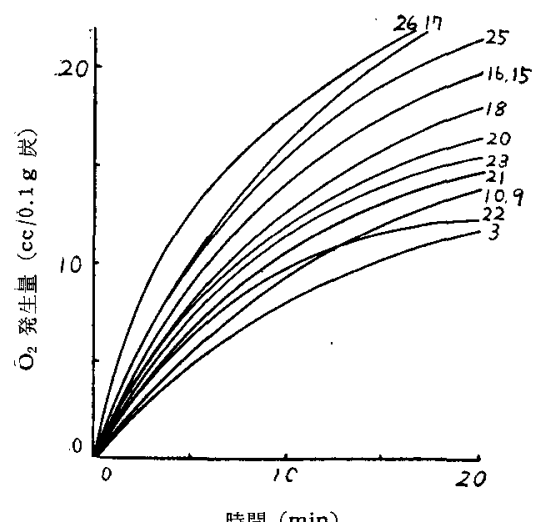
3. 第 2 回熱妚理
9. $\mathrm{AlCl}_{3} 1 \%$
10. $\mathrm{MnCl}_{2} 3 \%$
15. $\mathrm{NH}_{4} \mathrm{Cl} 3 \%$
16. $\mathrm{NH}_{4} \mathrm{Cl} 1 \%$
17. $\mathrm{NH}_{4} \mathrm{Cl} 0.5 \%$
18. $\mathrm{NH}_{4} \mathrm{Cl} 0.1 \%$
20. $\left(\mathrm{NH}_{2}\right)_{2} \mathrm{CO} 1 \%$
21. $\left(\mathrm{NH}_{4}\right)_{2} \mathrm{CO}_{3} 1 \%$
22. $\left(\mathrm{NH}_{4}\right)_{2} \mathrm{HPO}_{4} 1 \%$
23. $\mathrm{NH}_{4} \mathrm{Cl} 1 \%+\mathrm{ZnCl}_{2} 1 \%$
25. $\mathrm{NH}_{4} \mathrm{Cl} 1 \%+\mathrm{ZnCl}_{4} 10 \%$
26. $\mathrm{NH}_{4} \mathrm{Cl} 1 \%+\mathrm{ZnCl}_{2} 50 \%$

第 5 図白炭飞よる $\mathrm{H}_{2} \mathrm{O}_{2}$ 分解能 (備長炭)

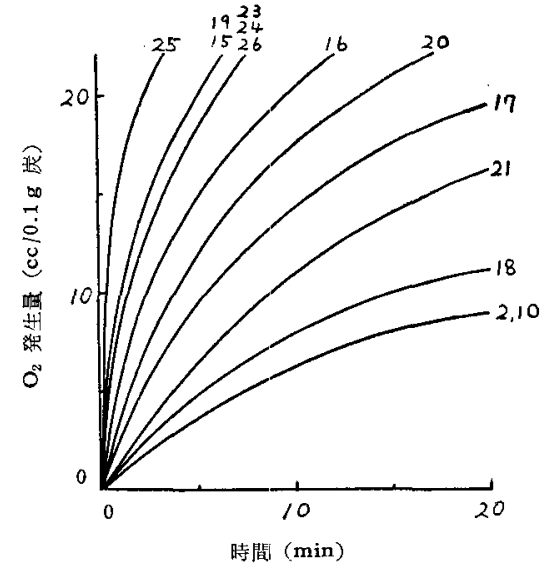

2. 第 1 回熱処理
10. $\mathrm{MnCl}_{2} 3 \%$
15. $\mathrm{NH}_{4} \mathrm{Cl} 3 \%$
16. $\mathrm{NH}_{4} \mathrm{Cl} 1 \%$
17. $\mathrm{NH}_{4} \mathrm{Cl} \quad 0.5 \%$
18. $\mathrm{NH}_{4} \mathrm{Cl} \quad 0.1 \%$

20. $\left(\mathrm{NH}_{2}\right)_{2} \mathrm{CO} 1 \%$

21. $\left(\mathrm{NH}_{4}\right)_{2} \mathrm{CO}_{3} 1 \%$

23. $\mathrm{NH}_{4} \mathrm{Cl} 1 \%+\mathrm{ZnCl}_{2} 1 \%$

24. $\mathrm{NH}_{4} \mathrm{Cl} 1 \%+\mathrm{ZnCl}_{2} 5 \%$

25. $\mathrm{NH}_{4} \mathrm{Cl} 1 \%+\mathrm{ZnCl}_{2} 10 \%$

26. $\mathrm{NH}_{4} \mathrm{Cl} 1 \%+\mathrm{ZnCl}_{2} 50 \%$

\section{による $\mathrm{H}_{2} \mathrm{O}_{2}$ 分解能}

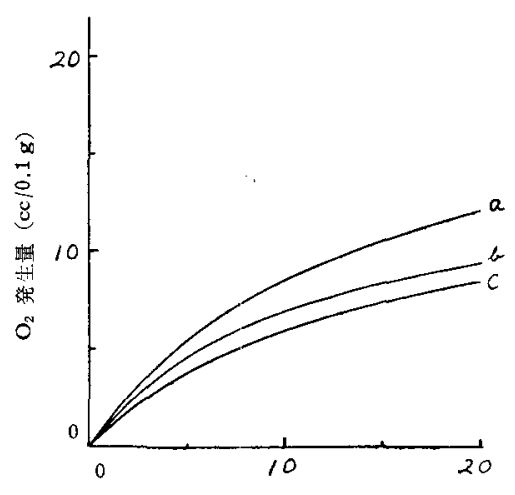

時䦔 $(\mathbf{m i n})$

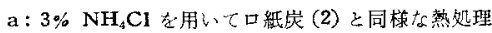

b: 热处埋 1 回

c： $1 \% \mathrm{NH}_{4} \mathrm{Cl}$ 老用いて可絟炭（2）上同侎な熱処理

第 7 图特殊樹炭汇小る $\mathrm{H}_{2} \mathrm{O}$ 分解能 (四国宸)

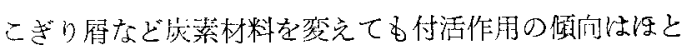
んど闹じである（第 4,5,6,7図）たが，借長炭，特殊

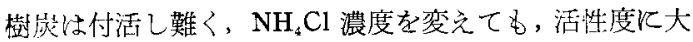

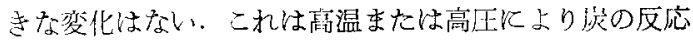
性が減少しているためでする。

備長炭の $\mathrm{NH}_{4} \mathrm{Cl}$ 付活欵素の過酸化水素分解反応速度 ほ時間だけと関係し，過酸化水素の濃度に恃無関係であ る. すなわち $\mathrm{H}_{2} \mathrm{O}_{2}$ 濃度に比較して, 活性中心の数が莧 だ少い故と思和る。.

口紙，口紙炭，のこぎり屏は付活しやすく， $\mathrm{NH}_{4} \mathrm{Cl}$ 濃 度が大きくなるに煺い，得られた炭素の活性度も大きく なっている。 


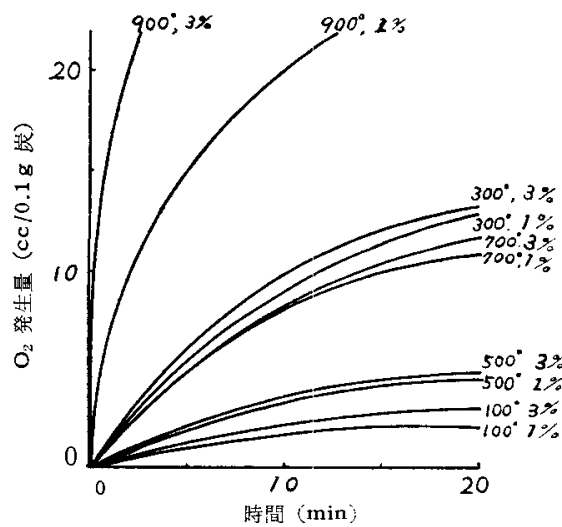

第 8 図 $\mathrm{NH}_{4} \mathrm{Cl}$ 含有の络温段に岁ける口紙荻 (2) 飞よる $\mathrm{H}_{2} \mathrm{O}$ ，分解能

C) Cahoon 氏放電試験法 $\mathrm{NH}_{4} \mathrm{Cl}$ で付活した璐 素の電気化学的性能を知るため, Cahoon 氏放電試験( ${ }^{(4)}$ を下記処理の炭素について試みた。

a) 口紙炭 $20 \mathrm{~g}, 40 \%$ 庶楛溶液 $32 \mathrm{cc}$

b) 口紙岸 $20 \mathrm{~g}, 40 \%$ 庶楉溶液 $32 \mathrm{cc} \mathrm{NH}_{4} \mathrm{Cl} 2 \mathrm{~g}$ 試料 a) は誡料 b) の対照として， $\mathrm{NH}_{4} \mathrm{Cl}$ を加完な いものである。庶糖溶液は結会剂として用いた。いずれ

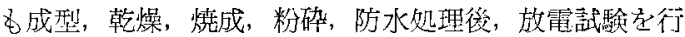
った。抵抗を加減して，150，200,250 mA て放雷を続 け，回路を閉じたま〉，陽極電位（飽和甘コウ電橝に刘 して）索空管電压計で測定した。

第 9 図に斌料 a)，b）の放電曲線在示したが， $\mathrm{NH}_{4} \mathrm{Cl}$ を添加した試料 b) の方が，武料 a) に比較して著しく 放電容星が増加していて，隄極孷素として性能の著しい 陷上を走す。

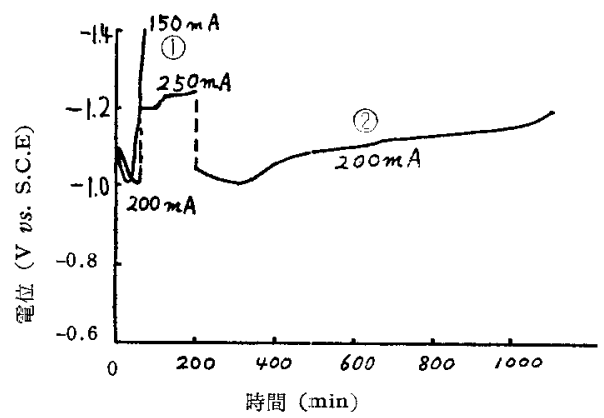

(1): 活性龙 (2): $\mathrm{NH}_{4} \mathrm{Cl}$ 付活宸

第 9 図 Cahoon 法による活性炭と不活性策 陽極の放電曲線

\section{3. 焼成六儿囲気上活性度亡の関係}

\section{1. 実験方法}

2.に颃いて述へたた試料は焼成時に生成与る瀻維素の

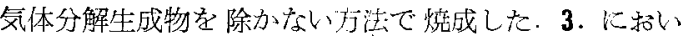

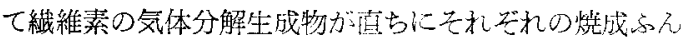

囲気にさらされて除かれる方法で武料索焼成し，その焼 成ふ九囲気と活性度との関係を研究した。すなわち，5 $\sim 10 \mathrm{~mm}$ に減压または $\mathrm{N}_{2}, \mathrm{H}_{2}, \mathrm{O}_{2} 3 \%+\mathrm{N}_{2} 97 \%, \mathrm{O}_{2} 5 \%$ $+\mathrm{N}_{2} 95 \%, \mathrm{CO}_{2}$ の挌の招の気王の気流中で，口紙を崖化 と同時比扵活焼成した，付活剂としては $\mathrm{NH}_{4} \mathrm{Cl}(1,3,5$ \% 浴液）を用いた，気体の流速は娍圧の場合を除いて， $0.1 \mathrm{l} / \mathrm{min}$ 索用いた。絓色 1 枚ずつ円柱状に成形し， 5 枚分を一列飞並べ，横型雪気炣の石英管中で炭化と同 時に付活唫成した，このようにして得た炭素について， 前報 ${ }^{(3)}$ と闹じ方法で過酸化水素の分解速度孝測定した。

\section{2. 実験結果亡考察}

A) $\mathrm{NH}_{4} \mathrm{Cl}$ 溶液を含浸させずに， 口紙だけを種々の らん国気で烧成すると，炭索の活性度は $\mathrm{CO}_{3}>5,9 \mathrm{O}_{2}+$ $95 \% \mathrm{~N}_{2}>\mathrm{H}_{2}=\mathrm{N}_{2} \fallingdotseq$ 減圧 のふ九目気の順序となり，酸化

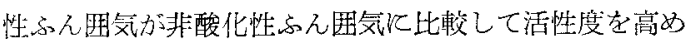
ることがかかる(第 10 図)。

B) 付活剂として $\mathrm{NH}_{4} \mathrm{Cl} 1,3,5 \%$ 溶液をとれぞれ含 没さぜた埸合でも $\mathrm{NH}_{4} \mathrm{Cl}$ の濃度が同じならば，上記と

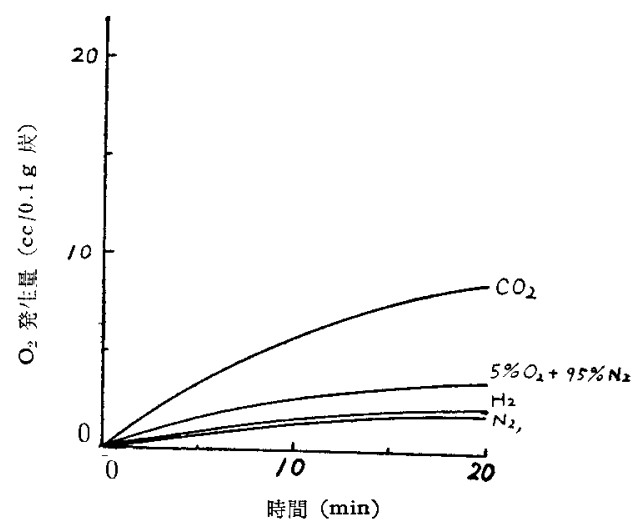

第 10 図 種々のらえ囲気で焼成した口紙 炭飞よる $\mathrm{H}_{2} \mathrm{O}_{2}$ の分解能

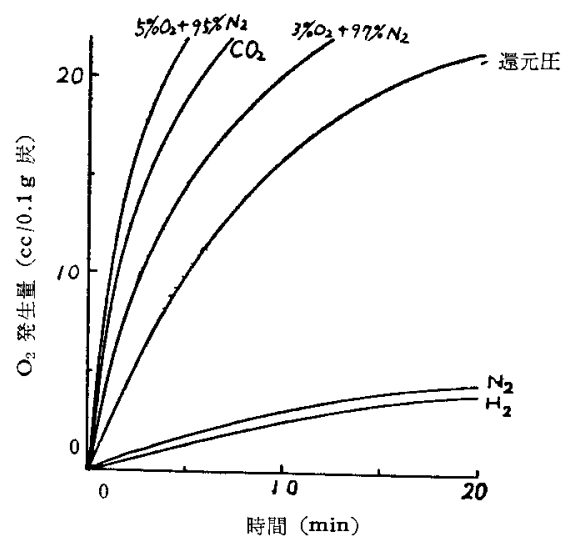

第 11 図 各種示九圈気て $\mathrm{NH}_{4} \mathrm{Cl}$ 添加活性岸 とよる $\mathrm{H}_{2} \mathrm{O}_{2}$ 分解能 $\left(1 \% \mathrm{NH}_{4} \mathrm{Cl}\right)$ 


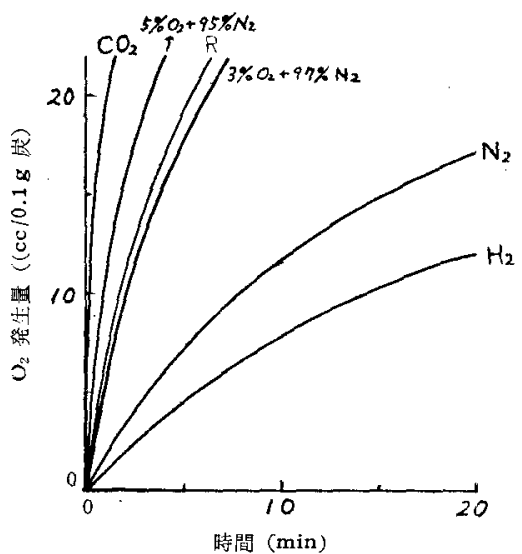

第 12 图第 11 図と同し(3\% $\left.\mathrm{NH}_{4} \mathrm{CI}\right)$

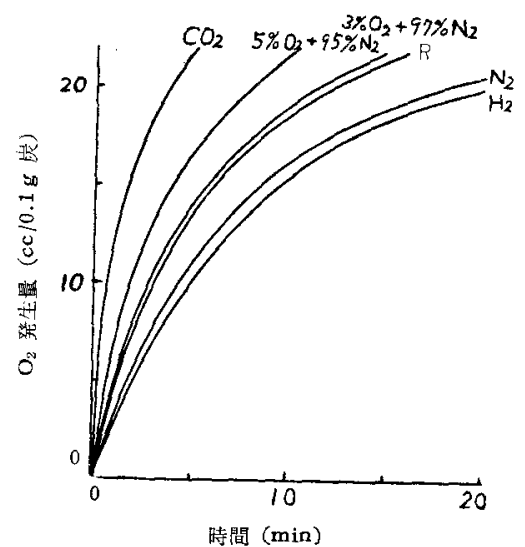

第 13 图第 11 图之同じ $\left(5 \% \mathrm{NH}_{4} \mathrm{Cl}\right)$

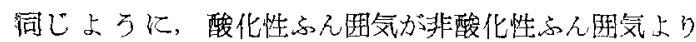
も，炭素の活性度を高める(第 $11 \sim 13$ 図).

非酸化性ふえ国気では $\mathrm{NH}_{4} \mathrm{Cl}$ の濃度の增加に従い， 活性度の高い炭素を得るが, 酸化性らん囲気では $\mathrm{NH}_{4} \mathrm{Cl}$ の濃度が3，6の場合に最高の活性度の炭素主得た。

C）焼成心ん囲気が同し場合，才べて含浸さ求る $\mathrm{NH}_{4} \mathrm{Cl}$ の濃度が堌加するに従い孷化收率も増加する（第

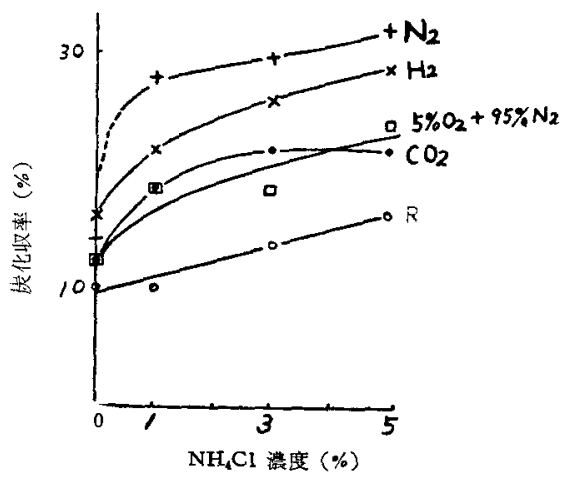

第 14 图 $\mathrm{NH}_{4} \mathrm{Cl}$ 濃度と炭化收率の関保
14 园).

D) 植々の岑素の水蒸気汲着特性 テルマノワーゲ 孝用いて $30^{\circ} \mathrm{C}$ 亿扣ける水蒸気财着等温線を測定した (简15 龱).

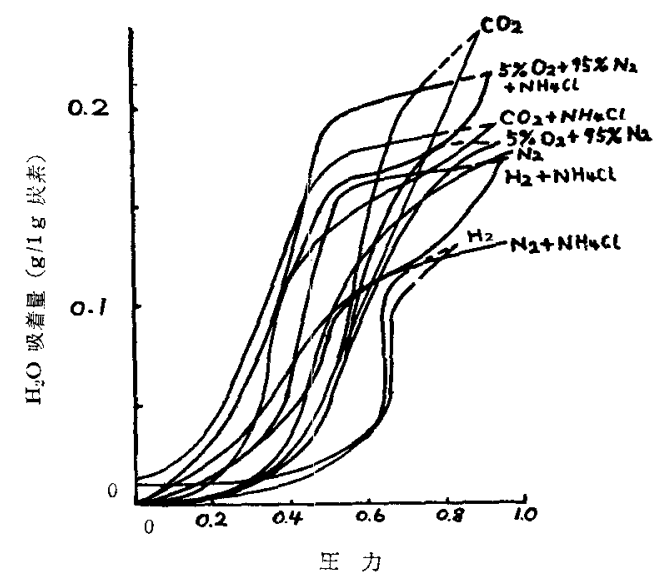

第 15 図 種々のガスふえ囲気に挌ける口紙炭 少与水蒸気吸着等温線

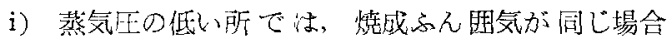
$\mathrm{NH}_{4} \mathrm{Cl}$ 付活した孤素は $\mathrm{NH}_{4} \mathrm{Cl}$ 付活しなかった楸素比 校して水蒸気根着琵加多い。

ii）薏気压の低い所では，水素ガス焼成ふ九用気で焼 成した敌素の水蒸気吸着舅が特に少い。

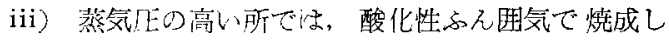

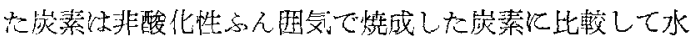
蒸気吸着䎸が多い。

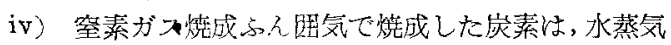
败着一脱着によるヒステリシスが認められなかった。

\section{4. 結 論}

空気湿霍池用炭素陽極の筫の向上を目的として $\mathrm{H}_{2} \mathrm{O}_{2}$

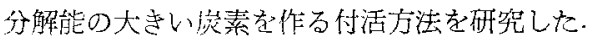

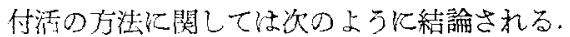

（1）浔せき剤としてアンモニウム基又はアる，基を 合它化含物が有效である。

(2) 洷成らん国気として炭酸ガス，または邅当量の 酸素豆含む䆟素気流が有效である。

（3）烧成温度は約 $900^{\circ} \mathrm{C}$ が適当である。

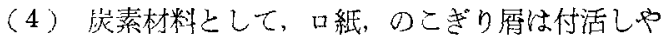
すく, 满辰炭, 特殊樹炭队付活し難い。

また塩化アンモンで付活した炭素と，これる行なわな かった炭素上をCahoon 氏法で，测定し比較すると塩化 アンモン付活性放電容量を增加させることがわかった。

塩化アンモン付活は活性度を高め且つ宸化收率を良く する。しかし一方酸化性焼成らて囲気は活性度を高める が炭化收率を雳くすること，持よび $300,500^{\circ} \mathrm{C}$ と階段的 付活によって一度得られた涯性度が低下することなどか 
ら、アンモニウム基の付活作用と酸化性らえ柬気の付活 作用とは別筒と行われるものと思われる。

この実験快，電気化学協会一次電池技術委員会の仕事 の一部であり，文部省科学矿究費の援助受けた。

(昭 33-4-1 受理!)
文 献

(1) 牧野三郎:空気電池 Carbo-Norit: Brit. Pat. 468,496 (1937)

(2) E.C. Larsen, J.H. Walton: $J$. Phys. Chem., 44, 70 (1940) ; P.F. Bente, J.H. Walton : ibid., 47, 329 (1943); P.F. Bente, J.H. Walton : ibid., 47, 133 (1943)

（3）上池 修，成子栄三，沢田五十萑：電化，22，608 (1954)

(4) N.C. Cahoon: J. Electrochem. Soc., 99, 343 (1952) 松本䅞忠博, 西 朋太, 网田辰三: 笔化, 22, 612 (1954)

\section{空気電池の放電特性と過酸化水素分解能} (炭素表面錯化合物による研究)*

\section{Relation between Performances of the Air-depolarized Cell and Catalytic Activity of Charcoals}

桖 $\underset{\text { Yoshiyuki MAKI }}{\text { 良 }}$

\section{1. 緒言}

ガス吸着剤、脱色剂，触媒流どとして使用される活性 炭は, その由来する原料, 賦活法などにより性能值がか なり大幅に変化するし，また使用する対象によって性能 值選度性があらわれること没どが知られている。空気

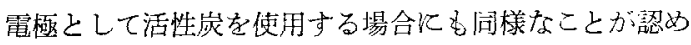

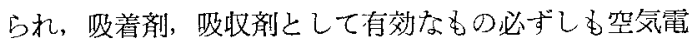
極上して有效とはいえない。したがってどの上うな原材

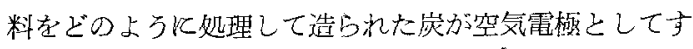

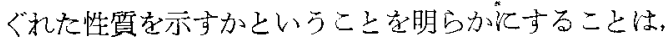
この電極を製造する場合最も重要なことで, 彷来の研究 も柱とんどこの点にしばられて来ているが，幾多の業續 の集積があるにるかかからずな扰判然としない面が多 い.けだし空気電極に括いては活性炭の化学的婊面構造 扣よび粒子個々の大さ，形状，その凝集状態などに加うる に, 電極自体の幾何学的形状なぞが䨘要な役割をなして 招り、これらの要因を判然と分截して研究することがか なり困難なためであるうと考完られる。しかし活性炭の 能某的な性質が空気電極の動作特性汇反映されると考克 るの怙過去幾多の実験から徽してもきわめて妥当なこと であって, 各種の間接的活性度判定法もはとんどこのよ うな仮定の上に立脚しているように考光られる。この代 表的例が電極党構成する粉沫活性炭の過酸北水素分解能 を比較する方法(1)で，その大なるものが電極としての 特性が良いとされているが，分解能測定の精度を十分考

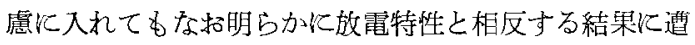
遇することがしばしば起り，この方法の侵頼性について

* 略和 32 年 7 月 16 日電気化学協会一次電池披術委員会講演

**工業技術院電気試験所（東京都千代田区永田町 201 )
路問在有する研究者も多い。しかしこの相関性を否定す る上うな結果についてはさらに十分検討の必要がある. その理出として分解能の測定方法よりむしろ電極の動作 特性のとり方問題があると考えられる。すなかち試料 活性炭粉末劣交る一定の形の電極に成形し特性を測定す る末での過程に粉末試料の特泩を変形する惧れのあるよ うな二次的操作が加光られている場合が多い，たと党ば 粘絬剂老加兄て高温で再焼成したり，焼成電極に撥水処 理を施すなどである。皇た，焼成電極を武料とする場合 には，分解能測定用の試料劣得るため電極の表面を削り とりすでて撥水処理を施したものであれば，撥水用を 除去するために溶剤抽出などの操作が行われるのが一般 である。これらの操作はいずれる原材料の特性を変化す る危険性が多分にある、李た成形された電極について及 ても，電解液伩刘する霄極作動表面のぬれ方，導電端子 上宣極体之の相対的位置，接触状態の差異などによる特 性のバラッキるある。本研究では従来の研究にみとめら れる以上のような点を特に注意して，末ず，放電特性の 测定方法，装置沶よび特性值の評洒方法について検討を 加党, ついで過酸化水素分解能測定飞用いた粉末試料を 粉末状態の委委放電特性の測定に用いることにより試料 炭の特性の二次的操作住上る変化極力防止するように 乙て過酸化水素分解能と電池の特性との関係について 再検鄙を行ったるのである，京た，この雨者の関係を確 かめるについて，試料の物理的状態，たと充ば粒度分 有, 見掛の密度, 表面皘などの変化を最小限にとどめ, 電極体を楧成した時試料の充てん（填）状態を可及的に 均一にして, 空気の拡散状態の差に基く特性のバラッキ 防止するようにしたこのために放電特性かかなり 異ると予想される黒炭（松）上白炭（なら）の二種を兄 